\title{
ANALYSIS OF ACCEPTANCE OF E-HEALTH APPLICATION BY USERS IN PRIMARY HEALTHCARE CENTER IN SURABAYA CITY
}

\author{
Ni Made Mira Wahyu Astani ${ }^{1}$, Ni Luh Putu Arum Puspitaning Ati ${ }^{2}$, Ernawaty ${ }^{3}$ \\ ${ }^{1}$ Department of Health Promotion and Behavioral Sciences, Faculty of Public Health, Airlangga University, \\ Surabaya, Indonesia \\ ${ }^{2,3}$ Department of Policy and Health Administration, Faculty of Public Health, Airlangga University, Surabaya, \\ Indonesia \\ Address Correspondence : Ni Made Mira Wahyu Astani \\ Email : mademirawa@gmail.com
}

\begin{abstract}
This study used the observational quantitative method to analyze the acceptance of information technology in the form of thee-Health. The theory of acceptance was further analyzed using the Unified Theory of Acceptance and Use of Technology (UTAUT) model. UTAUT model is the latest unified model that is an appropriate to explain the acceptance and use of information systems. The research objective was to analyze perceptions of the use of eHealth applications in the Surabaya City Health Center. The research design method used was cross-sectional design. The selected samples of 100 people were determined by multistage sampling in primary healthcare centers in every area of Surabaya. The independent variables in this study were performance expectancy, effort expectancy, social influence and behavioral intention while the dependent variable was the use of e-Health applications. Data were collected through questionnaires delivered via interviews. The results showed that the lowest indicator of acceptance by the users was the time needed to input data category to the e-Health application. This study concludes that the acceptance of e-Health by users primary healthcare centers in Surabaya is low. This study suggests a more widespread dissemination of information regarding the benefits of the use of e-Health along with technical assistance and guidance on the use of e-Health applications.
\end{abstract}

Keywords: UTAUT Model, e-Health application, primary healthcare center, acceptance

\begin{abstract}
ABSTRAK
Penelitian ini merupakan pendekatan kuantitatif observasional untuk menganalisis penerimaan teknologi informasi yaitu e-Health. Teori penerimaan dengan menggunakan model Teori Terpadu Penerimaan dan Penggunaan Teknologi (UTAUT). Model UTAUT merupakan model gabungan terkini yang dianggap paling tepat dalam menjelaskan penerimaan dan penggunaan suatu sistem informasi. Tujuan penelitian untuk menganalisa persepsi penggunaan aplikasi e-Health di Puskesmas Kota Surabaya. Desain penelitian yang digunakan yaitu potong-lintang. Sampel terpilih sebanyak 100 orang, yang ditentukan berdasarkan pengambilan sampel acak bertingkat pada Puskesmas di tiap wilayah Surabaya. Variabel bebas dalam penelitian ini adalah harapan kinerja, harapan usaha, pengaruh sosial dan, niat perilaku sedangkan variabel terikat adalah penggunaan aplikasi eHealth. Pengambilan data dilakukan dengan kuesioner yang disampaikan melalui wawancara. Hasil penelitian menunjukkan bahwa indikator akseptasi paling rendah oleh pengguna puskesmas di Kota Surabaya adalah ketika aplikasi e-Health menghabiskan banyak waktu untuk input data. Penelitian ini menyimpulkan rendahnya akseptasi aplikasi e-Health oleh pengguna aplikasi e-Health di Puskesmas Kota Surabaya. Penelitian ini menyarankan untuk mengadakan sosialisasi lebih meluas terkait manfaat dari penggunaan aplikasi e-Health, mengadakan kegiatan pendampingan dan pengarahan mengenai teknis penggunaan aplikasi e-Health.
\end{abstract}

Kata Kunci: Model UTAUT, aplikasi e-Health, Puskesmas, penerimaan

\section{INTRODUCTION}

The development of information and communication technology causes changes in human life. The use of information technology within the health sector can help people access to health services faster and in a more practical way.
A successful system depends on the acceptance and use of individuals. Acceptance and use can be measured through the level of satisfaction in using the system or technology and its direct impact on increasing the productivity of an organization (Sari, 2012). 
Table 1. Users of e-Health Applications in the City of Surabaya by Region in the Period of 2015 and 2016

\begin{tabular}{rlrcrcrr}
\hline No & $\begin{array}{l}\text { Surabaya } \\
\text { area }\end{array}$ & \multicolumn{3}{c}{ Year 2015 } & \multicolumn{3}{c}{ Year 2016 } \\
\cline { 3 - 8 } & & $\begin{array}{c}\text { Puskesm } \\
\text { as } \\
\text { visitors }\end{array}$ & $\begin{array}{l}\text { User } \boldsymbol{e} \text { - } \\
\text { Health }\end{array}$ & $\begin{array}{c}\text { Persentase } \\
(\boldsymbol{\%})\end{array}$ & $\begin{array}{c}\text { Puskesm } \\
\text { as } \\
\text { visitors }\end{array}$ & $\begin{array}{c}\text { User } \boldsymbol{e} \text { - } \\
\text { Health }\end{array}$ & $\begin{array}{c}\text { Persent } \\
\text { ase }(\%)\end{array}$ \\
\hline 1 & $\begin{array}{l}\text { Central } \\
\text { Surabaya }\end{array}$ & 55.355 & 11.784 & 17,07 & 60.943 & 13.111 & 20,37 \\
\hline 2 & $\begin{array}{l}\text { North } \\
\text { Surabaya }\end{array}$ & 114.383 & 605 & 1,25 & 122.267 & 5.076 & 4,13 \\
\hline 3 & $\begin{array}{l}\text { East } \\
\text { Surabaya }\end{array}$ & 83.385 & 1.723 & 2,48 & 102.595 & 5.878 & 6,38 \\
\hline 4 & $\begin{array}{l}\text { West } \\
\text { Surabaya }\end{array}$ & 150.888 & 18.890 & 7,26 & 114.411 & 28.969 & 27,04 \\
\hline 5 & $\begin{array}{l}\text { South } \\
\text { Surabaya }\end{array}$ & 84.587 & 1.104 & 1,45 & 82.660 & 11.374 & 14,68 \\
\hline & TOTAL & 488.598 & 34.106 & & 482.876 & 64.408 & \\
\hline & Avarage & 97.720 & 6.821 & 5,90 & 96.575 & 12.882 & 14,52 \\
\hline
\end{tabular}

The Surabaya city government implemented an innovation to make it easier for the public to self-register as patients. EHealth or electronic health, which is driven by information technology, has been integrated into all primary healthcare centers and district general hospitals in Surabaya; it allows people to register an appointment as long as they have access to the internet. Through e-Health registration, long queues can be avoided, and patients can also estimate their time of attendance to the intended health facility.

Since its implimentation in 2014, eHealth online patient registration in the city of Surabaya has shown an increase in users. However, the average number of users has not yet reached the target of the Surabaya City Health Office. The following data are patients in primary healthcare centers who used e-Health in 2015-2016 in each area of Surabaya. Table 1 shows only $5.90 \%$ in 2015 and $14.52 \%$ in 2016 users did not reach the target of the Surabaya City Health Office. Therefore, it is necessary to reexamine the acceptance and use of the application. The e-Health iniciative has been running for 3 years, but its sucess for use will greatly depend on the acceptance process that occurs within the community.

There are many variations of Technology Acceptance Models (TAM) which best fit to the system or technology being developed. Consequently, this study will use the Unified Theory of Acceptance and Use of Technology (UTAUT) model developed by Venkatesh et al (2003). UTAUT is the latest unified model that is considered the most appropriate in explaining the acceptance and use of information systems (Yuniarti, 2016).

Figure 1. UTAUT Model

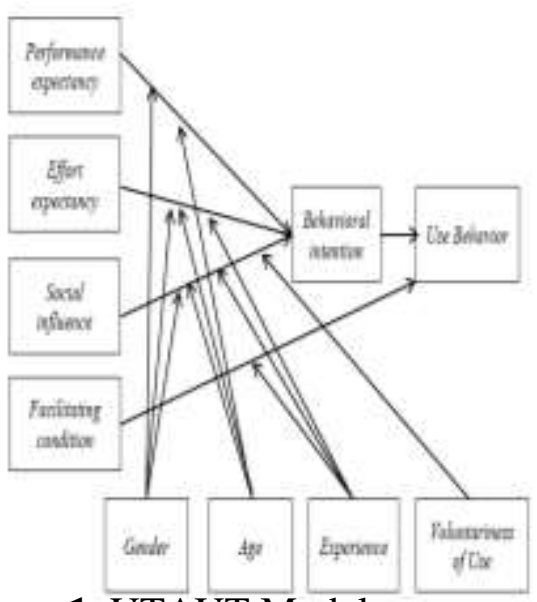

(Source : Venkatesh et al, 2003) 
Venkatesh et al. states that a person's intention to behave (behavioral intention) and behavior in using technology or information system (use behavior) will be influenced by their perceptions of performance and effort expectancy. Social influence and facilitating conditions are assessed from gender, age, experience, and voluntarism.

This study aims to analyze the acceptance of e-Health by primary healthcare center patients in the city of Surabaya using the UTAUT model. This study could determine the effect of an information system on the use of e-Health applications. Primary healthcare centers were chosen to investigate due to the presence of e-Health users. The acceptance of a technology application with the UTAUT variables requires an investigation of users' perception.

\section{METHODS}

This study was an observational study using the cross-sectional design. It was conducted in five primary healthcare center in the city of Surabaya, namely the primary healthcare centers of Ketabang, Dupak, Mojo, Jagir, and Simomulyo. The timeframe of this research was from April to May 2017. A total of 26,915 users were primary healthcare center patients who had used the e-Health application. The subjects studied were 100 people with an error tolerance limit of $10 \%$.

Primary data were obtained using the survey method, by administering questionnaires which were a modification of Venkatesh et al, (2003). Acceptance of an information system is influenced by several variables incorporated in the Unified Theory of Acceptance and Use of Technology (UTAUT) model. The research has passed an ethical test from Health Research Ethics Committee with No. 107KEPK.

\section{Performance Expectancy}

Perceved usefullness is the sub variable that will be assesed in performance expectancy. Venkatesh et al, (2003) defines perceived usefulness as a system or technology that can improve performance. If an individual considers the system to be useful, then that individual will use it. Perceived usefulness in using the e-Health application reflects the public perception regarding the benefits when registering patients at the primary healthcare center. Perceived usefulness has a strong and consistent relationship with information systems and shows results that supports perceived usefulness as a significant determinant of an individual's willingness to use information systems.

\section{Effort Expectancy}

Effort expectancy is assessed from three sub variables: perceived ease of use, complexity, and ease of use. The Technology Acceptance Model (TAM) theory shows that perceived usefulness is influenced by perceived ease of use, in which people thought technology's benefits and its simple use. When an individual acknowledges a technology system is useful, a sense of comfort will be established (Santoso, 2010). A person's level of confidence will increase if there is minimum effort in using the e-Health application (Arum, 2018).

Complexity is defined as the level of public viewpoint towards a system that is relatively difficult to understand and use (Arum, 2018). Sabihaini's research (2006) finds that the relationship between complexity and technology utilization was negative. The more complex the innovation, the lower the level of acceptance and use. The complexity level of e-Health is determined by public perception where, whether or not, it is deemed to be difficult to understand and use. Complexity as a subvariable is used to determine public understanding when users enroll patients using e-Health. 
Ease of use, in this context, refers to the level of public perception in the ease of using a system or technology. This is supported by Davis's (1989) research which finds that the ease of use affected the initial decision in making a system because it was a significant determinant of interest in someone using information technology.

\section{Social Influence}

Social ifluence assesses one sub variable which is subjective norm. According to Fishbein and Ajzen (1975, in Suhendro, 2009), subjective norm is the level of individual belief about the behavior people should do. Subjective norm is the level of public perception of social influence to use a system or technology. These several statements are in line with Arum's (2018) research saying that the level of public perception was influenced by those around them who were using eHealth. Subjective norm as a sub-variable is used to determine the subjective effect of using the e-Health application.

\section{Facilitating Condition}

Facilitating condition is assessed from two sub-variables which are perceived behavioral control and facilitating condition. Perceived behavioral control indicates the control of one's perception, the belief that can either support or hinder the use of a system or technology (Arum, 2018). Perceived behavioral control is assessed based on the level of public perception towards internal and external constraints on the use of e-Health application. For example, the individual perceptions of other people's beliefs can affect the intention to use the application.

Facilitating conditions are assessed based on objective factors in an easy-towork environment, including the provision of computer support (Arum, 2018). Facilitating conditions have two dimensions related to resources andtechnological capabilities. According to (Diani et al., 2017), resource facilitating condition is the availability of resources needed such as time and money to bring up a certain behavior. Meanwhile, technology facilitating condition is support in terms of technology infrastructure for easy-use systems or applications.

\section{Behaviour Intention to Use}

Behavior intention to use is assessed from one subvariable. It is defined as an individual's behaviour in using a technology or information system. (Andryanto, 2016) added that an individual's behavior will appear if there is a desire or interest to do so. This is assessed based on public interest in using the e-Health application (Arum, 2018). Behavior intention to use is evaluated from several indicators such as intention to use in the future and plans for frequent use in the future.

\section{Use Behavior}

According to a research by Sa'idah (2017), use behavior is the intensity or frequency of use of information technology or systems. Use behavior is assessed based on a person's satisfaction in using the eHealth application and the belief in easy use. Those two aspects can increase the productivity of an individual. As previously stated by Venkatesh et al, (2003), a person's intention to behave (behavioral intention) and behavior to use technology (use behavior) will be influenced by other people's perceptions.

\section{RESULTS}

In the UTAUT theory, several variables such as facilitating conditions and behavioral intention to use affect use behavior. Furthermore, performance expectancy, effort expectancy, and social influence are the three variables that affect behavioral intention to use. According to Nugroho (2012), the emergence of interest in the use of technology (behavioral intention) comes from a desire to use the 
system continuously with the assumption that they have access to information.

\section{Characteristics of Respondents}

Table 2. Individual Characteristics of EHealth Users in Surabaya

\begin{tabular}{|c|c|c|}
\hline \multirow[t]{2}{*}{$\begin{array}{c}\text { Individual } \\
\text { Characteristics }\end{array}$} & \multicolumn{2}{|c|}{$\begin{array}{c}\text { Application Users } \\
\text { e-Health }\end{array}$} \\
\hline & $\mathbf{N}$ & $\%$ \\
\hline \multicolumn{3}{|l|}{ Sex } \\
\hline Female & 76 & 76,00 \\
\hline Male & 24 & 24,00 \\
\hline \multicolumn{3}{|l|}{ Age } \\
\hline $0-11$ years & 0 & 0 \\
\hline $12-16$ years & 6 & 6,00 \\
\hline $17-25$ years & 8 & 8,00 \\
\hline 26-35 years & 16 & 16,00 \\
\hline $36-45$ years & 42 & 42,00 \\
\hline$>45$ years & 28 & 28,00 \\
\hline \multicolumn{3}{|l|}{ Level of education } \\
\hline No school & 0 & 0 \\
\hline SD & 5 & 5,00 \\
\hline Junior High & 12 & 12,00 \\
\hline High school & 58 & 58,00 \\
\hline PT & 25 & 25,00 \\
\hline \multicolumn{3}{|l|}{ Type of work } \\
\hline Civil servants & 6 & 6,00 \\
\hline Private employees & 23 & 23,00 \\
\hline entrepreneur & 13 & 13,00 \\
\hline TNI / POLRI & 2 & 2,00 \\
\hline Housewife & 44 & 44,00 \\
\hline Health workers & 3 & 3,00 \\
\hline Student & 9 & 9,00 \\
\hline \multicolumn{3}{|l|}{ Availability of } \\
\hline Have & 86 & 86,00 \\
\hline Not & 14 & 14,00 \\
\hline \multicolumn{3}{|l|}{ Voluntary Use } \\
\hline Volunteer & 91 & 91,00 \\
\hline Not voluntary & 9 & 9,00 \\
\hline \multicolumn{3}{|l|}{ Experience of Use } \\
\hline $1-3$ times & 47 & 47,00 \\
\hline 4-6 times & 16 & 16,00 \\
\hline$>6$ times & 37 & 37,00 \\
\hline
\end{tabular}

Individuals will be interested in using a new technology if they believe that it will improve their performance, have easy access, and have effects to the surrounding environment. At the end, using thie system will normalize the behavior and be affected by the availability of its facilities. Based on the results in Table 2, the age group of eHealth application users tends to be in the late adulthood or 36-45 years, making it difficult for them to navigate the application.

The majority of respondents were female. The respondents were mostly high school graduates, and the majority were working as housewives. Most of the respondents voluntarily used e-Health and have experienced using it 1 to 3 times.

\section{UTAUT Model}

The Unified Theory of Acceptance and Use of Technology (UTAUT) model has several acceptance indicators, including perceived usefulness, perceived ease of use, complexity, ease of use, subjective norm, perceived behavioral control, behavioral intention to use, and use behavior.

\section{Performance Expectancy}

Performance expectancy variables are categorized based on the perceived usefulness sub-variable and are divided into several indicators, namely e-Health speed, ease, and use in patient registration.

Table 3 shows usefulness in patient registration was the lowest indicator for the e-Health application. Users in the City of Surabaya assesed the usefulness by a mean score of 3.27 out of 4.00 . However, this lowest sore does not represent negativity towards e-Health. It has provided great benefits for the community to get certainty in the primary healthcare center. Previously, the community cannot receive services in a timely manner as the services are adjusted to the service hours of health workers. 
Table 3. Perceived Usefulness Indicators of E-Health Users in Surabaya

\begin{tabular}{|c|c|}
\hline $\begin{array}{c}\text { Indicator } \\
\text { Perceived Usefulness }\end{array}$ & $\begin{array}{l}\text { Mean score } \\
\quad(0-4)\end{array}$ \\
\hline E-Health application as part of patient registration & 3.29 \\
\hline The E-Health application can help faster patient registration & 3.32 \\
\hline The E-Health app can make patient registration easier & 3.4 \\
\hline The E-Health application is useful in patient registration & 3.27 \\
\hline Average Total Score & 3.32 \\
\hline
\end{tabular}

\section{Effort Expectancy}

The effort expectancy variable is categorized based on the perceived ease of use subvariable. This subvariable is divided into several indicators: ease of operating, ease of getting, and ease of set up e-Health in addition to the proficiency in using the application).

Table 4. Users of e-Health applications in the city of Surabaya are based on the Effort Expectancy Variable Indicator

\begin{tabular}{|c|c|c|c|}
\hline $\begin{array}{l}\text { Effort Expectancy } \\
\text { Variable }\end{array}$ & Indicator Variable Effort Expectancy & $\begin{array}{c}\text { Mean } \\
\text { score } \\
(0-4)\end{array}$ & $\begin{array}{c}\text { Average } \\
\text { Total } \\
\text { Score }\end{array}$ \\
\hline \multirow{4}{*}{$\begin{array}{c}\text { Subvariable } \\
\text { Perceived Ease of } \\
\text { Use }\end{array}$} & $\begin{array}{l}\text { Ease of learning to operate the e-Health } \\
\text { application. }\end{array}$ & 3.07 & \multirow[t]{4}{*}{2.98} \\
\hline & $\begin{array}{l}\text { Ease of getting the e-Health application for } \\
\text { patient registration. }\end{array}$ & 3.24 & \\
\hline & The e-Health app is easy to set up. & 2.76 & \\
\hline & $\begin{array}{l}\text { Ease of having the ability to use the e-Health } \\
\text { application (advanced). }\end{array}$ & 2.86 & \\
\hline \multirow{4}{*}{$\begin{array}{l}\text { Subvariable } \\
\text { Complexity }\end{array}$} & $\begin{array}{l}\text { The time spent enrolling patients with the e- } \\
\text { Health app was compared with the manual } \\
\text { method. }\end{array}$ & 2.11 & \multirow[t]{4}{*}{2.05} \\
\hline & $\begin{array}{l}\text { The e-Health application is complex and } \\
\text { difficult to understand. }\end{array}$ & 2.15 & \\
\hline & $\begin{array}{l}\text { The e-Health application spends a lot of time } \\
\text { on data input. }\end{array}$ & 1.89 & \\
\hline & $\begin{array}{l}\text { The length of time to learn to use the e-Health } \\
\text { application. }\end{array}$ & 2.03 & \\
\hline \multirow{4}{*}{$\begin{array}{c}\text { Subvariabel ease } \\
\text { of use }\end{array}$} & $\begin{array}{l}\text { The system interactions on the e-Health } \\
\text { application are clear and understandable. }\end{array}$ & 3.33 & \multirow[t]{4}{*}{2.88} \\
\hline & Trust to easily get e-Health application. & 2.65 & \\
\hline & Trust that the e-Health app is easy to use. & 2.69 & \\
\hline & $\begin{array}{l}\text { Ease of learning to operate the e-Health } \\
\text { application }\end{array}$ & 2.84 & \\
\hline
\end{tabular}

Table 4 shows that, the effort expectancy can be assessed from the subvariable perceived ease of use. The lowest indicator, at 2.76, was in public trust where users did not believe that it was easy to set up. This is because people believe that the use of the e-Health is difficult to set up.
The effort expectancy variable is also categorized based on the complexity, namely the time to register patients with the e-Health compared to manual methods, the complexity of e-Health, the long time it takes to input data, and the learning period for the application. In the complexity 
subvariable, the lowest indicator in users of e-Health, scored 1.86 out of 4.00 , is the long data inputing. This factor is also supported by the belief that using e-Health is relatively difficult to understand and use.

The effort expectancy based on ease-of-use is divided into several indicators, namely clear and understandablesystem interaction in eHealth, easy access to e-Health, easy eHealth use, and ease of learning to operate e-Health.

In the ease-of-use subvariable, the lowest indicator is the ease in access the eHealth application, scored 2.65 out of 4.00. The users believed that the application was considered relatively inaccessible.

\section{Social Influence}

Social ifluence variable is categorized based on the subjective norm subvariable. The subvariable is then divided into two indicators, which are: the influence of surrounding people that use e-Health and the existence of a service institution that requires its use.
Based on Table 5, it can be concluded that the lowest indicator in users of e-Health applications in the City of Surabaya is the influence of the surrounding people, which totals at 2.83 out of 4.00 . This is due to the influence of people around them who consider the use of the e-Health application when registering pasients at the primary healthcare center.

Table 5. Subjective Norm Indicators of EHealth Users in Surabaya

\begin{tabular}{lc}
\hline \multicolumn{1}{c}{$\begin{array}{c}\text { Indicator } \\
\text { Subjective Norm }\end{array}$} & $\begin{array}{c}\text { Mean } \\
\text { score } \\
(\mathbf{0 - 4})\end{array}$ \\
\hline $\begin{array}{l}\text { Influence from people around } \\
\text { them to use the e-Health } \\
\text { application }\end{array}$ & 2.83 \\
\hline $\begin{array}{l}\text { Service institutions require the } \\
\text { use of the e-Health application. }\end{array}$ \\
\hline \multicolumn{2}{c}{ Average Total Score } \\
\hline
\end{tabular}

\section{Facilitating Condition}

The facilitating condition variable is categorized based on the perceived behavioral control subvariable

Table 6. Facilitating Condition of E-Health Users in Surabaya

\begin{tabular}{|c|c|c|c|}
\hline $\begin{array}{c}\text { Variable } \\
\text { Facilitating } \\
\text { Condition }\end{array}$ & $\begin{array}{c}\text { Indicator Variable Facilitating } \\
\text { Condition }\end{array}$ & $\begin{array}{c}\text { Mean } \\
\text { score } \\
(0-4)\end{array}$ & $\begin{array}{c}\text { Average } \\
\text { Total } \\
\text { Score }\end{array}$ \\
\hline \multirow{4}{*}{$\begin{array}{l}\text { Subvariable } \\
\text { Perceived } \\
\text { Behavioural } \\
\text { Control }\end{array}$} & $\begin{array}{l}\text { The system in the e-Health application } \\
\text { can be controlled. }\end{array}$ & 2.71 & \multirow[t]{4}{*}{2.98} \\
\hline & $\begin{array}{l}\text { Knowledge of how to use the e-Health } \\
\text { application. }\end{array}$ & 3.02 & \\
\hline & $\begin{array}{l}\text { Resources (gadgets / computers / e- } \\
\text { Kiosk) to use the e-Health application. }\end{array}$ & 3.02 & \\
\hline & $\begin{array}{l}\text { Having knowledge and resources can } \\
\text { make it easier to use the e-Health } \\
\text { application. }\end{array}$ & 3.16 & \\
\hline \multirow{4}{*}{$\begin{array}{l}\text { Subvariable } \\
\text { Facilitating } \\
\text { Condition }\end{array}$} & $\begin{array}{l}\text { There is a guide to using the e-Health } \\
\text { application. }\end{array}$ & 2.98 & \multirow[t]{4}{*}{3.02} \\
\hline & $\begin{array}{l}\text { Instructions for using the e-Health } \\
\text { application. }\end{array}$ & 3.15 & \\
\hline & $\begin{array}{l}\text { There are people who accompany you } \\
\text { when you have trouble using the e- } \\
\text { Health application. }\end{array}$ & 2.92 & \\
\hline & $\begin{array}{l}\text { There is a guide to using the e-Health } \\
\text { application. }\end{array}$ & 2.98 & \\
\hline
\end{tabular}


The subvariable is divided into several indicators, namely the controllability of the e-Health system, knowledge on how to use the application, and resources (gadget/computer/e-kiosk) to use e-Health.

Based on Table 6, facilitating conditions can be assessed from the perceived behavioral control that the lowest indicator is the system controllability variable at 2.71 . It is still difficult for the public to control the system on the e-Health application. The result shows there was low public perceptions of internal and external constraints in using the application.

The facilitating condition variable is categorized based on the facilitating condition sub-variables. The subvariables are divided into several indicators such as a guide to using e-Health, user manuals, and having a guide to help. In this subvariable, the lowest indicator was having a guide to help with difficulties, scored 2.92. This is due to the fact that there are resources that support users to the e-Health application. However, the respondents believed that they would find it difficult when no one helped them use the application.

\section{Behaviour Intention to Use}

Table 7. Users of e-Health applications in the city of Surabaya based on the Behavior Intention to Use indicator

\begin{tabular}{|c|c|}
\hline $\begin{array}{c}\text { Indicator } \\
\text { Behaviour Intention to Use }\end{array}$ & $\begin{array}{c}\text { Mean } \\
\text { score } \\
(0-4)\end{array}$ \\
\hline $\begin{array}{l}\text { Intention to use the e-Health } \\
\text { application in the future. }\end{array}$ & 3.19 \\
\hline $\begin{array}{l}\text { Plans for frequent use of the e- } \\
\text { Health application. }\end{array}$ & 3.24 \\
\hline Average Total Score & 3.22 \\
\hline $\begin{array}{l}\text { The behavior intentio } \\
\text { variable is categorized base } \\
\text { subvariables. The sub-variables } \\
\text { into two indicators: the intentior }\end{array}$ & $\begin{array}{l}\text { to use } \\
\text { on its } \\
\text { divided } \\
\text { o use the }\end{array}$ \\
\hline
\end{tabular}

e-Health application in the future and the plan to frequently use the e-Health application.

Based on Table 7, the results of this study indicate that the public's intention to use the e-Health application in the future for patient registration was still low at 3.19. However, this result shows the community intends to use the e-Health application in the future. However, if there is still a perceptual influence due to factors that do not support the use of e-Health, it will result in public intention loss of using the e-Health continously.

\section{Use Behaviour}

Table 8 shows that the use behavior indicator in users was low. A total of 8 respondents $(8 \%)$ used e-Health via cellphone, and 5 respondents $(5 \%)$ used it through 2 applications at once via cellphone and website. These results present that the respondents rarely used the e-Health application on their cellphones/devices as they first need to download the application and create a registration account.

Tabel 8. Use Behaviour of E-Health Users in Surabaya

\begin{tabular}{lll}
\hline $\begin{array}{l}\text { Indikator } \\
\text { Use Behaviour }\end{array}$ & $\boldsymbol{n}$ & $\mathbf{\%}$ \\
\hline $\begin{array}{l}\text { E-Health application } \\
\text { on HP }\end{array}$ & 8 & 8.00 \\
\hline e-Kiosk & 23 & 23.00 \\
\hline Website & 30 & 30.00 \\
\hline $\begin{array}{l}\text { E-Health application } \\
\text { on HP and e-Kiosk }\end{array}$ & 7 & 7.00 \\
\hline $\begin{array}{l}\text { E-Health application } \\
\text { on HP and Website }\end{array}$ & 5 & 5.00 \\
\hline e-Kiosk and Website & 17 & 17.00 \\
\hline $\begin{array}{l}\text { All three } \\
\text { Average Total }\end{array}$ & $\mathbf{1 0 0}$ & $\mathbf{1 0 0 , 0 0}$ \\
\hline Score & & 10.00 \\
\hline
\end{tabular}


Table 9. Respondents' Reasons for Using the E-Health Application in Surabaya Primary Healthcare Centers in 2018

\begin{tabular}{lcc}
\hline $\begin{array}{l}\text { Reasons for using the } \\
\text { e-Health application }\end{array}$ & n & $\%$ \\
\hline Easy to use & 21 & 21.00 \\
\hline Easy to Access & 22 & 22.00 \\
\hline $\begin{array}{l}\text { Interesting registration } \\
\text { method }\end{array}$ & 6 & 6.00 \\
\hline No need to queue & 16 & 16.00 \\
\hline $\begin{array}{l}\text { Practical / Time is } \\
\text { faster }\end{array}$ & 19 & 19.00 \\
\hline $\begin{array}{l}\text { Referral from the } \\
\text { Puskesmas }\end{array}$ & 9 & 9.00 \\
\hline $\begin{array}{l}\text { Can Choose Time } \\
\text { Average Total Score }\end{array}$ & $\mathbf{1 0 0}$ & $\mathbf{1 0 0 . 0 0}$ \\
\hline
\end{tabular}

The results of the study indicate that the reason most respondents, as many as 22 respondents, used e-Health at primary healthcare centers was for ease of access (see Table 9). These results indicate that the community have easier access online through cellphones, websites, or eKiosks. However, it was found that the eHealth method, summing up to 6 respondents $(6 \%)$, was very low. The respondents argued that the e-Health application was not interesting because it was difficult to understand.

\section{UTAUT Variable Recapitulation}

In the UTAUT variables, the recapitulation of subvariables obtained included perceived usefulness, perceived ease of use, complexity, ease of use, subjective norm, perceived behavioral control, and behavior intention to use. The results of the recapitulation of e-Health application, based on Table 10, showed that the variable with the lowest average score was found in the complexity subvariable which reached a poor score of 2.05. This implies that people believe that the e-Health application is relatively difficult to understand and use. The public assessment on the use of e-Health is high enough to effect the use of the e-Health application for patients' registration.

Table 10. UTAUT Variables of E-Health Users in Surabaya

\begin{tabular}{lcl}
\hline \multirow{2}{*}{$\begin{array}{l}\text { SubVariable } \\
\text { UTAUT }\end{array}$} & \multicolumn{2}{c}{$\begin{array}{c}\text { Application Use } \\
\text { e-Health }\end{array}$} \\
\cline { 2 - 3 } & Mean Score & Category \\
\hline $\begin{array}{l}\text { Perceived } \\
\text { Usefulness }\end{array}$ & 3.32 & $\begin{array}{l}\text { Very } \\
\text { good }\end{array}$ \\
\hline $\begin{array}{l}\text { Perceived } \\
\text { Ease of Use }\end{array}$ & 2.98 & Good \\
\hline Complexity & 2.05 & Bad \\
\hline Ease of Use & 2.88 & Good \\
\hline $\begin{array}{l}\text { Subjective } \\
\text { Norm }\end{array}$ & 2.84 & Good \\
\hline $\begin{array}{l}\text { Behaviour } \\
\text { Intention to } \\
\text { Use }\end{array}$ & 3.22 & Good \\
\hline
\end{tabular}

\section{DISCUSSION}

(Broderick et al., 2003) defined eHealth as the application of the internet or other related technologies in the health care industry as a way to improve access, efficiency and effectiveness. To formulate a long-term strategic plan, the World Health Organization (2011) recommends the development of e-Health services in various health fields such as in administrative, legal, and regulatory frameworks, as well as public and private partnership mechanisms.

The Surabaya city government has developed the e-Health innovation in the form of an online patient registration application since 2015 to give people easy access to health services. In addition, through the E-Health application, patients can make referrals to hospitals such as Mohammad Soewandhi Hospital and Bhakti Dharma Husada Hospital that have integrated e-Health (Hafizh, 2016). Acceptance of the e-Health application, according to Venkatesh et al, (2003), can be seen from sex (gender), age, experience, and volunteerism (voluntariness). 
E-Health can be accessed from anywhere through a communication device such as a cellphone or a gadget that are connected to the internet. Ease of access is one of the main principles of the E-Health application. Moreover, people who do not have the means to register patients online, the Surabaya City Government has provided a platform to access the E-Health application in the form of E-Kios (public service kiosks).

\section{UTAUT Variables Concept Based on the Use of E-Health Applications}

Perceptions of the use of the eHealth application can be seen from the acceptance by primary healthcare center users based on four variables such as performance expectancy, effort expectancy, social influence and facilitating conditions. Venkatesh et al, (2003) stated that several variables have direct influence on the acceptance of eHealth users and the behavior of using eHealth based on the UTAUT variables.

\section{Performance Expectancy}

Performance expectancy is a person's level of confidence in using technology or information systems to improve a performance at work Venkatesh et al, (2003). (Khairiyah, 2017), argues that performance expectancy describes the benefits of the system for its users related to productivity, task performance, effectiveness, the importance of a task and overall usefulness. The depiction of the performance expectancy variable can be seen from the system benefits for the wearer, namely perceived usefulness, extrinsic motivation, job fit, and relative advantage (Arum, 2018). Looking only at the subvariable of perceived usefulness is not enough as other assessment indicators might be relevant to the public as users of technology or systems.

Performance expectancy in this study indicates the level of public confidence in using the e-Health application which will provide benefits in patient registration. The study shows that the community's assessment of the use of the application for registering patients was low. This is because the community did not to receive services in a timely manner as the health workers and patients had to adjusts to the service hours. People who register online should be able to come directly to the polyclinic according to schedule. However, in practice, people who have registered online still need to queue again. The performance expectancy in the use of the e-Health application was in the good category, but the e-Health application was still considered useless by the community, especially the respondents.

\section{Effort Expectancy}

Effort expectancy or business expectation is the use of technology or systems on the basis of convenience (Venkatesh et al, 2003). (Khairiyah, 2017) stated, that effort expectancy deals with the clarity of the purpose of using technology or information systems and the ease of using the system to get goals in accordance with user expectations. Measuring the ease of system usecan be identified from 3 subvariables, which are perceived ease of use, complexity, and ease of use.

Effort expectancy represents the level of the ease of use of e-Health applications. Effort expectancy in this study indicates the ease of using the eHealth application in patient registration. Analysis on the sub-variable perceived ease of use showed that trust was low in the use of the e-Health application that is too difficult to manage. The ease of use subvariable shows that the public believed that e-health was easily accesssable.

Meanwhile, the research results on complexity show lengthy data input was the reason of low public trust. The application was difficult to understand resulting in low use in patient registration in primary healthcare centers. Due to the change of habit in patient registration, application users are not sure that it will 
help improve their performance (Haryono et al., 2015). There are still many technical problems with the e-Health application, thus increasing the time for users accessing the system. This subvariable falls into the bad category because it is considered quite difficult for the community to register patients.

\section{Social Influence}

Social influence is the use of technology or information systems based on support or influence from outside individuals (Venkatesh et al, 2003). According to (Wang and Chou, 2014), social influence can affect individuals from both perspectives related to social expectations and observed behavior from others. Social influence is a variable that creates individual acceptance of technology, either directly or indirectly, mediated by attitude (Khairiyah, 2017). Social influence can determine the extent to which social relationships can influence the behavior of using systems and technology through input from other people (Arum, 2018). However, this study only focuses on the subjective norm subvariable. Therefore, this subvariable has an effect on how to behave using this technology.

Social ifluence, in this study, indicates the level of trust from outside influences, such as from other people or institutions. This study shows a lack of influence from outside individuals and the surrounding public. This is supported by previous research which stated that social influence can directly influence behavioral intention (Rivai, 2014). Influence of the institution should be stronger to require the community, especially in the primary healthcare centers, to use the e-Health application.

\section{Behaviour Intention to Use}

According to (Khairiyah, 2017), intention is a desire, plan, or belief that is oriented towards a goal. Behavioral intention is defined as someone's thoughts about how likely it is to bring up a behavior. The intention to use is an attitude towards the use of technology in the form of acceptance or rejection which has an impact on an individuals use of information technology at work (Heijden, et al, 2003). Behavioral itention to use in this study indicates an intention in people's behavior whether or not to use the e-Health application.

It was found that the community lacked the intention to use the e-Health application in the future due to the low interest in using the e-Health application. This is in line with the research of Andre Wahyudi, (2017), which states that the reduced intention to use e-Health was due to the limited e-Kiosk service machines placed in hospitals and health centers, the lack of data updates in e-Health, and unclear complaint mechanism. Interest in using the e-Health application was low because this app was relatively new, not stable, and had frequent network failures (Arum, 2018).

\section{Use Behaviour}

Use behavior is an actual condition in the use of a technology or information system (Venkatesh et al, 2003). Use behavior comes from someone's intention or desire to use a system or technology. It can be seen to which extent individuals are satisfied with the application, the belief in its easy use, and the confidence that it would increase user's productivity. Yuniarti's research (2016) states that behavioral intention has a positive and significant influence on use behavior.

Use bhavior indicates the level of behavior in using the e-Health application by the community in the work area of the Surabaya City primary healthcare centers. The community used of cellphones or gadgets in patient registration and had low interest in understanding and using eHealth. The shortcomings of this study are the types of gadgets used for accessing the e-Health application. The e-Health application can only be accessed through 
devices that have an internet connection. However, not all types of devices can access the e-Health application with the same display, therefore the difficulty in registering a patient may vary depending on the type of device used.

\section{CONCLUSION}

The results showed the acceptance of the e-Health application at Surabaya City primary healthcare centers with the lowest value was the complexity indicator. While the acceptance with the highest value was the perceived usefulness indicator. This study is expected to be an input in the use of the e-Health application. This study recommends more extensive socialization regarding the benefits of using the e-Health application, mentoring, and briefing activities regarding the technical use

\section{REFERENCE}

Andre Wahyudi, Shabrina Mufidah, Panji Windu Arista, F. M. (2017) Melejitkan Pengoptimalan E-Health dalam Meningkatkan Kualitas Pelayanan Kesehatan di Surabaya.

Andryanto, R. (2016) Pengaruh Kepercayaan, Persepsi Manfaat, Dan Persepsi Kemudahan Penggunaan Terhadap Minat Beli di Toko Online (Studi Empiris yang Dilakukan Pada olx.co.id di Yogyakarta). Yogyakarta.

Arum, N. L. P. (2018) Analisis Penggunaan Aplikasi E-Health Oleh Masyarakat Berdasarkan Unified Theory Of Acceptance And Use Of Technology (Studi Di Wilayah Kerja Puskesmas Kota Surabaya). Universitas Airlangga, Surabaya.

Broderick, M. et al. (2003) 'E-Health Defined', pp. 1-11.

Davis, F. D. (1989) 'Perceived Usefulness, Perceived Ease of Use, and User Acceptance of Information Technology', MIS Quarterly, 13(3), pp. 319-340.

https://doi.org/10.2307/249008

Diani, M. M. et al. (2017) Pengukuran Niat Pengguna Terhadap Penggunaan Aplikasi City113 Berdasarkan Decomposed Theory Of Planned Behavior Pada Kota Surabaya (Studi Kasus: $\quad$ Surabaya Timur) Measurement. Institut Teknologi Sepuluh Nopember Surabaya.

Hafizh, D. A. (2016) 'Inovasi Pelayanan Publik: Studi Deskriptif tentang Layanan E-Health dalam Meningkatkan Pelayanan Kesehatan di Puskesmas Pucang Sewu Kota Surabaya', Kebijakan dan Manajemen Publik Volume, 4(3), pp. 1-9. doi: ISSN 2303 - 341X biasa.

Haryono, S. et al. (2015) 'Pengaruh Shopping Orientation, Social Influence, dan System Terhadap Customer Attitude Melalui Perceived Ease of Use (Studi pada Apple Store)', Jurnal Manajemen Pemasaran Petra, 3(1), pp. 1-10.

Heijden, H. Van Der, Verhagen, T. and Creemers, M. (2003) 'Understanding Online Purchase Intentions; Contributions from Technology and Trust Perspectives', European Journal of Information Systems, 12, pp. 41-48. https://doi.org/10.1057/palgrave.ejis .3000445

Khairiyah, W. (2017) Hubungan Antara Performance Expectancy, Efort Expectancy, Social Influence, dan Facilitating Condition Pada Intensi Dosen dalam Penggunaan Learning Management System (LSM) di Universitas Hasanuddin Makassar, Skripsi. Universitas Hasanuddin.

Nugroho, J. J. (2012) Analisis FaktorFaktor yang Mempengaruhi Minat Pemanfaatan dan Penggunaan ETicket (Studi Empiris pada Biro Perjalanan di Kota Semarang). Universitas Diponegoro.

Rivai, M. B. (2014) Penerapan Model The Unified Theory Of Acceptance And 
Use Of Technology (UTAUT) Untuk Mmahami Tingkat Penerimaan dan Penggunaan E-Learning (Be-Smart) di Fakultas Teknik Universitas Negeri Yogyakarta. Universitas Negeri Yogyakarta.

Sa'idah, N. (2017) 'Analisis Penggunaan Sistem Pendaftaran Online (EHealth) Berdasarkan Unified Theory of Accepptance and Use Of Technology (UTAUT)', Jurnal Administrasi Kesehatan Indonesia, 5(1), pp. 72-81.

Sabihaini (2006) 'Analisis Pemanfaatan Teknologi Informasi dan Kinerja Individual (Studi pada Rumah Sakit di Yogyakarta)', Jurnal Widya Manajemen \& Akuntansi, 6(1), pp. $1-16$.

Santoso, B. (2010) 'Pengaruh Perceived Usefulness, Perceived Ease of Use, dan Perceived Enjoyment terhadap Penerimaan Teknologi Informasi', Jurnal Studi Akuntansi Indonesia PENGARUH, pp. 1-15.

Sari, I. N. (2012) Analisa Model UTAUT pada Brawijaya Knowledge Garden (Studi Eksplanatif Penerimaan dan Penggunaan Sistem Brawijaya Knowledge Garden pada Universitas Brawijaya). Universitas Airlangga. Available at: gdlhub-gdl-s1-2013sariindahn-23097-

5.FULLTEXT.pdf.

Suhendro (2009) Pengaruh Perceived Usefulness Dan Perceived Ease of Use Dalam Penggunaan Sistem Informasi Keuangan Daerah. Universitas Sebelas Maret.

Venkatesh, V., M.G. Morris, G. B. D. and F. D. D. (2003) 'User Acceptance Of Information Technology: Toward A Unified View', Mis Quarterly, 27(3), pp. 425-478. https://doi.org/10.2307/30036540

Wang, E. S. and Chou, N. P. (2014) 'Consumer Characteristics, Social Influence, and System Factors on Online GroupBuying Repurchasing Intention.', Journal of Electronic
Commerce Research, 15(2), pp. 119132.

Yuniarti (2016) Upaya Peningkatan Penerimaan dan Penggunaan P-Care Oleh Petugas Puskesmas di Kabupaten Sidoarjo Dengan Metode Unified Theory of Acceptance and Use of Technology. Universitas Airlangga. 